УДК 792+82-2 (477)

Горболіс Л. М.

доктор філологічних наук, професор

Сумський державний педагогічний університет

\title{
ТЕАТР КОРИФЕЇВ У ЗМАГАННЯХ \\ ЗА НАЦІОНАЛЬНУ ІДЕНТИЧНІСТЬ УКРАЇНЦІВ \\ (НА МАТЕРІАЛІ ТЕАТРОЗНАВЧИХ ПРАЦЬ КІНЦЯ ХІХ - ПОЧАТКУ ХХ СТ.)
}

У статті на основі пращь Д. Антоновича, М. Вороного, Я. Мамонтова, спогадів Л. Старичької-Черняхівської досліджується роль украйнського театру корифеїв в утвердженні начіональної самобутності украйнців; акчентується на засобах впливу украӥнського театру на глядача кіния $X I X-$ початку XX $\mathrm{cm}$. 
Ключові слова: начіональна ідентичність, театр, самосвідомість, літературний прочес, «нова драма».

В статье на основе работ Д. Антоновича, М. Вороного, Я. Мамонтова, воспоминаний Л. Стариикой-Черняховской исследуется роль украинского театра корифеев в утверждении начиональной самобытности украинчев; акчентируется на средствах влияния украинского театра на зрителя конча XIX-начала XX в.

Ключевые слова: начиональная идентичность, театр, самосознание, литературный прочесс, «новая драма».

The article deals with the role of the Ukrainian theater of coryphaei's in establishing the Ukrainian national identity on the basis of work of D. Antonovych, M. Voronyi, Y. Mamontov, memoirs of L. Staritska-Chernyahivska. The article focuses on the means of influence of Ukrainian theater spectators in the end of XIX - beginning of the XX century.

Keywords: national identity, theater, self-actualization, the literary process, "a new drama."

Понад 100 років тому М. Вороний писав: «B останній час мені нерідко доводилось чути, щзо писати про украӥнський театр стало майже неможливим. Легше, мовляв, перейти по натягненій линві Ніагарський водопад, ніж написати правдиву критичну статтю, не зачепивиись за артистичне самолюбство, не наразивиись на непорозуміння» [Вороний 1996: 270]. Минув час, проте писати про театр корифеїв із різних причин все ще залишається складно.

Чимало питань, пов'язаних зі становленням і розвитком українського театру, попри тривалість їхнього дослідження, відкриті для студій. Завдання статті - на основі театрознавчих праць та спогадів істориків і критиків українського театру виявити параметри змагальних дій українського театру за національну самобутність українського народу.

У статтях «Триста років українського театру. 1619-1919» Д. Антоновича, «Театральне мистецтво і український театр», «Український театр у Києві» М. Вороного, «Драматургія I. Тобілевича», «Українська драматургія передреволюційної доби (19001917)» Я. Мамонтова, у спогадах «Двадцять п’ять років українсь- 
кого театру» Л. Старицької-Черняхівської засвідчена провідна роль українських драматургів і театру в культурно-мистецькому русі другої половини XIX - початку XX ст., у пробудженні в українців почуття національної гідності, формуванні історичної та політичної свідомості.

Театр, «як засіб єднання людей» [Вороний 1996: 282], мав своїм завданням духовно й морально консолідувати народ. Саме тому ставлення до нього українців мало бути «як до першорядної культурно-національної справи $і$, разом з тим, як до засобу найяскравішої демонстрачії своєї начіональної мови і культури» [Триста років українського театру 2003: 124]. Таким вимогам відповідав театр корифеїв, щоправда «ворушилом украӥнського руху» [Триста років українського театру 2003: 147] він став не відразу. Як зауважує Д. Антонович, перед 1876 роком українська література, за незначним винятком, не виходила за межі простонародних сюжетів, позаяк не бачила в цьому потреби. «Зрештою, в ті часи і в тих обставинах виробився в громаді такий настрій, що і п'єса з інтелігентського життя в украӥнській мові, і просто інтелігенти в європейському убранні, що забалакали б на счені по-украйнськи, викликали б сміх у глядачів, і навіть іноді у людей, що вважали себе свідомими украйнцями» [Триста років українського театру 2003: 148-149]. Тобто українською мовою в театрі мали говорити ті, хто не спілкувався нею в щоденному житті - генерали, інспектори. Виконати це було складно з двох причин: по-перше, цензурних, адже україномовна інтелігенція й чиновники - то відкрите пропагування української мови; по-друге, непідготовлена публіка в україномовних героях при рангах могла вбачати неправдоподібність. Тому чи й не першорядним завданням культурних діячів стало виховувати, а почасти й завойовувати публіку, «ту широку безідейну масу люду, що складає трунт "театральных посетителей"» [Вороний 1996: 306].

Царські заборони обезкровили репертуар театру тематично й ідейно на тривалий час. Так, стверджує М. Вороний, «українська 
драма самою природою речі і наслідком цензурних заборон мусила бути тільки народною» [Вороний 1996: 336]. Драматурги, режисери усілякими способами намагалися обходити заборони, власноруч калічили свої твори, переробляючи їх по кілька разів на догоду цензурі.

Одним із перших, хто зробив доволі сміливі кроки на захист українського слова й утвердження театру, був М. Старицький, написавши п'єсу «Талан», у якій артисти говорили українською мовою - у цьому, звісно, довелося переконувати цензора, проте справа вирішилася позитивно (див. про це: [2, 339]).

Водночас театр зіткнувся 3 іншою не менш важливою проблемою - $з$ невиробленістю української мови. I саме в цей час, коли мова мала утверджуватися, успішно засвоюватися й розвиватися, над нею Дамокловим мечем зависли Емський указ і Валуєвський циркуляр. І все ж свідомі українці вважали своїм обов'язком активізувати й поширити залучення українського слова в суспільному й культурному житті. I знову одним із перших до таких конкретних заходів удався М. Старицький. Його сміливі кроки вводити в українську літературу слова, що вважалися неукраїнськими, кованими (наприклад, потужний, бойовище, байдужість тощо), отримували опір. На думку Д. Антоновича, «криза украӥнського культурного життя, може, більще, ніж указ 1876 року, примушували украйнський театр триматися простонародних побутових сюжеmів» [Триста років українського театру 2003: 149].

Додамо, що сцен з українського народного побуту, героїв у плахті й очіпкові тривалий час вимагала й публіка, якій така атрибутика була зрозумілою, яка дивилася на театр «як на "зрище" $i$ з однаковим ентузіазмом приймає i "Саву Чалого", $i$ "Чарівниџю", аби б лиш були ефекти - стрільби, пожежа тощо» [Вороний 1996: 312]. Театр, пояснює М. Вороний, певний час мусив потурати вимогам і смакам публіки, залежність від якої «утворила йому службове становище, що нерідко принижало його самостійне культурне значення і стримувало вільний розвій» [Вороний 1996: 320]. Невибагливі глядачі не з власної волі, а більше несвідомо творили не- 
вибагливий театр. Такий стан справ суттєво гальмував розвиток українського театру, на чому неодноразово у своїх працях наголошував Д. Антонович.

Вимушені заходи щодо звуження репертуару, «мовної політики» на сцені негативно позначилися на молодому і ще не зміцнілому національному русі, суттєво гальмували розвиток театрально справи. Все, що в 70-80 рр. відбувалося з українським театром, було складником продуманої і системної політики тогочасного уряду, позаяк Емський указ, Валуєвський циркуляр, як відомо, не лише забороняли українське слово, театр, пісню, а й завдавали жорстокого удару по ще не вповні заявленій, а, можливо, і не до кінця усвідомленій національній ідентичності, адже «силою чинників економічних та політичних українська національність того часу < ..> заховувала свої ознаки (мова, музика й ін.) в сільському побуті» [Триста років українського театру 2003: 373]. А тим часом, зауважує М. Вороний, «життя не жде, воно висуває на "порядок дневний" все нові й нові проблеми $і$ з кожним кроком ускладнює нашу начіональну творчу роботу. Украйнський рух росте гіпертрофічно, дезорганізовано $i$ потребуе координачії сил $i$ засобів» [Вороний 1996: 273]. Це усвідомлювали й культурні діячі. Тому на театральній і просвітницькій ділянці у цей час починають особливо активно працювати М. Кропивницький, І. Карпенко-Карий, які були глибоко переконані, що театр мусив стати «громадською школою, мусив учити, мусив доводити і переконувати» [Триста років українського театру 2003: 173]. Він мав, скористаємося думкою Л. Костенко, пояснювати народу самого себе. Внутрішне наповнення п'єси і іï̈ зовнішнє оформлення мали допомогти широким масам українців зосередити увагу на сутнісному, національному. Тобто театр водночас «мусив підняти національний стяг» [Триста років українського театру 2003: 144], стати «маніфестацією украӥнського слова» [Триста років українського театру 2003: 146].

У цей час М. Кропивницький створив український театр на народних засадах, започаткував українську артистичну школу. 
«Треба було справді надзвичайного завзяття, досвіду і хисту, щоб за такий короткий час з нічого (курсив М. Вороного. - Л. Г.) зробити таке симпатичне і стало зорганізоване діло, що розрослось тепер до дуже широких розмірів» [Вороний 1996: 244]. I саме етнографічний окрас став, на думку Д. Антоновича, важливим доказом «окремішності українського народу між слов'янськими народами» [Триста років українського театру 2003: 172], зокрема «від народу московського» [Триста років українського театру 2003: 172].

Прикметно, що заборона київського генерал-губернатора українських вистав у Київській, Волинській і Подільській губерніях (бо театр у цих краях - це політика), на думку Д. Антоновича, «давала наслідки якраз протилежні, і смисл українських вистав як політики через заборону тільки зростав і міцнішав» [Триста років українського театру 2003: 188]. Вистави $з$ участю М. Заньковецької, І. Садовського «підтримували стихійне почуття украйнства» [Триста років українського театру 2003: 189].

Важливі для формування національної свідомості українців речі будівничі театру представляли за допомогою зрозумілих і звичних речей, обставин, ситуацій, пояснюючи суттєве почасти через посередництво іронії, як, скажімо, П. Саксаганський комічні ролі - щиро, без дошкульного шаржування, зневаги й поганьблення. Так розкривалися майстерність, філософія праці актора, який мав «дар внутрішнього прозріння, інтуїтивного заглядання в душу людини» [Вороний 1996: 294].

Декорації, одяг, музика, танець були національними ідентифікаторами, етноатрибутами, що на них публіка реагувала почуттєво, переконуючись у значущості українського. Так у широкого загалу нашого народу формувалися засади самоповаги. Л. Старицька-Черняхівська згадує, як тогочасна критика рекомендувала російським трупам, що виставляли народні п'єси, «руководиться строгой мерой художественной правды и тою любовью к народу, образец которой представляет малороссийская 
труппа. Малороссийские пьесы потому и смотрятся с большим удовольствием и возбуждают необыкновенно ясное настроение в публике, что эта поэтическая и юмористическая струя в них соблюдены с большим уважением к малороссийскому типу (підкреслення моє. - Л.Г.)» [Триста років українського театру 2003: 310].

Так поступально, завдяки сумлінній праці, майстерності й таланту культурних діячів театр стає головним вогнищем українського культурного руху, твердинею української громади, утверджувачем національної ідентичності українського народу, на чому наголошував Д. Антонович: «...українська несвідома маса, яка ще не збулася зовсім національного почуття, знаходила в украйнському театрі відгомін на ті ноти, щуо ледве бриніли в глибині душі... Згуки рідного слова, мотиви рідної пісні, огонь рідного танџю - то все будило в душі щзось живе, але забуте, зогрівало душі теплом. ...до акторів виробилися відносини як до громадських діячів, що в перших лавах виносять національну украӥнську справу» [Триста років українського театру 2003: 173].

Завдяки таланту й зусиллям відданих театру людей свідомість широкого загалу українців помітно зросла. Публіка не приймала штучності в образах, неточності в деталях тощо. Л. Старицька-Черняхівська згадує випадок, коли водевільна артистка російської трупи п. Летар, забажавши взяти повний збір, узялася грати українську п'єсу без належного знання мови. Публіка була не задоволена ії мовленням (помилки, неправильні наголоси, перекручення слів тощо), а також убранням «сотниківни»: балетна спідничка, куценький корсажик, шовкові панчохи, черевички на високих підборах, кораблик на голові тощо. Публіка в залі свистіла, метушилася, галасувала, зчинивши гвалт. «То була вогненна образа за зневажливе відношення до українського слова; то була пекуча любов до пригнобленого свого рідного, яку розжеврів до полум'я украйнський театр. Стара рана, роз яттрена сльозою образи», - 
підсумовує Л. Старицька-Черняхівська [Триста років українського театру 2003: 276]. Так у «дім буття» (Г.-Г. Гадамер) не впускали тих, хто його зневажав, не розумів його законів і ганьбив. Про такі відкриті обурення проти псевдо пісень, квазіодягу, лжедекорацій ідеться в працях М. Вороного (див. про це: [Вороний 1996: 315, $318,319])$. Як бачимо, принципово новими рисами характеризується ставлення української публіки до театру. Час вимагав нових акторів, ролей, режисерів, п’сс, а також активних у сприйманні театральної продукції глядачів, на чому, зауважмо, свого часу наголошував Б. Шоу.

Український театр став активним вихователем широкого українського загалу, одним із дієвих засобів формування національної ідентичності, про що на початку XX ст. наголошувала театрознавча критика. Так, скажімо, М. Вороний зауважував: «Один звісний учений, етнограф Д., щзо друкує свої оригінальні праџі в Галичині, казав нам, що вважає Кропивничького своїм "хрещеним батьком". "Скоро побачив я театр Кропивницького, - казав він, я відразу почув себе украйнцем $і$ всю роботу свою з того часу направив виключно на національний шлях". Треба знати, що з Кропивницьким особисто він знайомий не був. А скільки ж то невідомих нам молодих сердець перейнялось нехай хоч хвилевим патріотичним запалом. А може, таки й навернулось до рідної справи; скільки щирих сліз пролили "карі очі дівочі"; скільки чесних думок, благородних почувань порушилось в душах глядачів під час українських вистав!» [Вороний 1996: 244].

Проте український театр не мав права зупинятися на досягнутому. У західноєвропейських культурах, як відомо, «на арену» виходила «нова драма», яку в українських реаліях слід було, поперше, якісно творити, по-друге, скеровувати в націєтворче русло. I, скажімо, у творах I. Тобілевича, який «передбачав не тільки європеїзачію украӥнського театрального мистецтва, але бачив $i$ дальший етап його» [Триста років українського театру 2003: 384], почали закладатися основи такої драми з орієнтуванням на дискусію 
й характерні ролі. Тогочасна прогресивна критика чекала від українського театру соціальної п'єси, драми настрою. Особливо це стало нагальною потребою після 1905 р., коли «для українського слова, як друкованого, так і на счені, виявилися хоч дуже обмежені, але все ж певні можливості» [Триста років українського театру 2003: 210]. Виникла нагальна потреба максимально оновити твори «силою психологічних нюансів» [Вороний 1996: 293]. Історичні п'єси I. Карпенка-Карого, М. Старицького, індивідуалізація образів, акторська майстерність «захоплювати і переконувати характеристичними образами» [Вороний 1996: 338] посутньо змінювали й оновлювали український театр. «Першою ластівкою неореалістичного репертуару» [Вороний 1996: 339] стає на нашій сцені «Брехня» В. Винниченка. У цей період особливі сподівання критики, театру й акторів на В. Винниченка, Лесю Українку, Л. Старицьку-Черняхівську, С. Черкасенка. Український театр мав силою нової культури «прокладати шляхи в сферу філософічної естетичної абстракції» [Вороний 1996: 277].

Змагання корифеїв українського театру за національну ідентичність українців - складний і тривалий процес, що вимагав потужної й самовідданої співпраці акторів, режисерів, драматургів, критиків і глядачів. Лише завдяки спільним зусиллям усіх учасників мистецько-літературного процесу можна було говорити про успіх.

\section{БІБЛІОГРАФІЯ}

Вороний 1996 - Вороний М. Поезії. Переклади. Критика. Публіцистика / М. Вороний ; упоряд. і приміт. Т. І. Гундорової. - К. : Наукова думка, 1996. - 704 с. Триста років українського театру 2003 - Триста років українського театру. 1619 1919 та інші праці / Д. Антонович та інш. / підгот. текстів, редагування і передмова Г. Ф. Семенюка та Л. С. Дем’янівської. - К. : «ВІП», 2003. - 418 с. 